\title{
Urethral Urothelial Papilloma
}

National Cancer Institute

\section{Source}

National Cancer Institute. Urethral Urothelial Papilloma. NCI Thesaurus. Code C5061.

Papilloma's are benign epithelial neoplasms that produce visible warty projections from epithelial surfaces. Papilloma's of the urethra typically occur just within or on the external meatus. - 2003 